\title{
ANALYSIS OF MASS CCD OBSERVATIONS TO IMPROVE THE ACCURACY OF ASTROMETRIC PROCESSING
}

\author{
Yu. Protsyuk, O. Kovalchuk \\ Research Institute: Mykolaiv Astronomical Observatory, Mykolaiv, Ukraine \\ yuri@nao.nikolaev.ua
}

\begin{abstract}
In Research Institute: Mykolaiv Astronomical Observatory (RI MAO) regularly observations of fields with open clusters on the KT50 telescope $(\mathrm{D}=500 \mathrm{~mm}, \mathrm{~F}=3000 \mathrm{~mm})$ with an Alta U9000 CCD camera $\left(3 \mathrm{k} \times 3 \mathrm{k}\right.$, FOV $\left.42.6^{\prime} \times 42.6^{\prime}\right)$ in drift scan mode are carried out. For this observation mode, we investigated the dependence of the differences between observed minus calculated $(\mathrm{O}-\mathrm{C})$ angular coordinates of reference stars in depending on $\mathrm{X}$ coordinate (direction perpendicular to the direction of charge transfer) in the CCD coordinate system. The data of observations of open clusters obtained in the RI MAO in 2011-2017 were used for the study. The data array used to obtain the distribution (O-C) for right ascension (RA) and declination (DEC), depending on $\mathrm{X}$, contains 62 million single observations of stars. The processing of the original data was carried out using the Astrometrica program with the reference catalogue UCAC4. The distribution of the $(\mathrm{O}-\mathrm{C})$ value as a function of $\mathrm{X}$ according to RA and DEC was obtained by the method of least squares. For the solution is a 10thdegree polynomial of $\mathrm{X}$ and a third degree from the integral intensity of the object in the image was used. The study showed the presence of significant (0.01-0.02)" systematic errors in the field of the matrix for bright stars $(10-12)^{\mathrm{m}}$. For faint stars, the amplitude of the constant part decreases significantly while maintaining the periodic component. Similar studies have also been carried out for a lot of CCD frames obtained from astronomical databases for other instruments. The results will be used to improve the accuracy of astrometric catalogues obtained with the KT50 telescope and to improve the accuracy of the proper motions of stars in the vicinity of open clusters.
\end{abstract}

Keywords: Astrometry - Data analysis - Astronomical data bases - Catalogues.

АБСТРАКТ. В науково-дослідному інституті "Миколаївська астрономічна обсерваторія" (НДІ МАО) проводяться регулярні спостереження площадок з розсіяними скупченнями на телескопі KT50 (D = 500 мм, F $=3000$ мм) 3 ПЗ3 камерою Alta U9000 $(3 \kappa \times 3 \kappa$, FOV $\left.42,6^{\prime} \times 42,6^{\prime}\right)$ в режимі синхронного переносу заряду. Для цього режиму спостереження ми досліджували залежність різниці (О-С) кутових координат опорних зірок залежно від координати X (напрямку, перпендикулярного напрямку переносу заряду) в системі координат ПЗЗ матриці. Для дослідження використовувались дані спостережень россіяних скупчень, отримані в НДІ МАО в 2011-2017 роках. Масив даних, який вико- ристовувався для отримання розподілу (O-C) для прямого піднесення (RA) та схилення (DEC), залежно від $\mathrm{X}$, містить 62 мільйони одиничних спостережень зірок. Обробка вихідних даних здійснювалася за допомогою програми Astrometrica 3 опорним каталогом UCAC4. Розподіл значень $(\mathrm{O}-\mathrm{C})$ як функції $\mathrm{X}$ відповідно до $\mathrm{RA}$ та DEC був отриманий методом найменших квадратів. Для рішення використовувались поліноми 10-го ступеня від $\mathrm{X}$ та третього ступеня від інтегральної інтенсивності об'єкта на зображенні. Дослідження показало наявність значних $(0,01-0,02) "$ систематичних помилок по полю матриці для яскравих зірок $(10-12)^{\mathrm{m}}$. Для слабких зірок амплітуда постійної частини значно зменшується при збереженні періодичної складової. Дослідження були також проведені для багатьох ПЗ3кадрів, отриманих з астрономічних баз даних для інших інструментів. Результати роботи будуть використовуватися для підвищення точності астрометричних каталогів, отриманих за допомогою телескопа КТ50, та для підвищення точності власних рухів зірок в розсіяних супченнях та їх околицях.

Ключові слова: Астрометрія - Аналіз даних Астрономічні бази даних - Каталоги.

\section{Introduction}

During the period from 2011 to 2017 at the KT-50 telescope $(\mathrm{D}=500 \mathrm{~mm}, \mathrm{~F}=3000 \mathrm{~mm})$ of the RI MAO (Shulga et al., 2012), equipped with a U-9000 CCD camera $\left(3 \mathrm{k} \times 3 \mathrm{k}\right.$, FOV 42.6' $\left.\times 42.6^{\prime}\right)$ (Apogee, 2018), a regular observations of open star clusters was performed in the framework of several scientific topics (Protsyuk et al., 2014; 2017). The U-9000 camera was used in synchronous charge transfer (drift scan) mode. The orientation of the camera along the $\mathrm{X}$-axis (row) coincides with the axis of declination on the celestial sphere, $\mathrm{Y}$ (column), respectively, with the axis of right ascension. For the entire period, about $62,000,000$ single observations of stars up to 17 th magnitude were obtained. Thus, for each line element (overall 3000 elements for the U-9000 camera), there is an array of more than 20,000 stars (on average). Processing of observations up to the (O-C) was performed using the Astrometrica program (Raab, 2018) in the UCAC4 reference system (Zacharias et al., 2013). Thus, we have a fairly well-statistically provided material for analyzing the distribution of the values $(\mathrm{O}-\mathrm{C})$ as a function of $\mathrm{X}$ (the direction is 
perpendicular to the direction of transfer of charge packets during the observation process).

\section{Investigations}

To study the behaviour of the value $(\mathrm{O}-\mathrm{C})$ depending on $\mathrm{X}$, we made samples $(\mathrm{O}-\mathrm{C})$ for each $\mathrm{X}$ and intensity interval, and then we calculated the average value $(\mathrm{O}-\mathrm{C})$ for each specific $X$ and the interval of stellar magnitudes. We performed the calculation in several iterations, discarding the samples with too large values $(\mathrm{O}-\mathrm{C})$ by the criterion of $3 \sigma$. Thus, we obtained the table values of the average value $(\mathrm{O}-\mathrm{C})$ for each $\mathrm{X}$ of the $\mathrm{CCD}$ matrix in a given interval of stellar magnitudes. For example, consider several graphs that display the resulting table data. In Fig. 1 shows a graph of the distribution of $(\mathrm{O}-\mathrm{C})$ values depending on declination for stars of the 12th stellar magnitude. As you can see $(\mathrm{O}-\mathrm{C})$ has a certain constant component at the level of 0.01 mas, and a variable reaching 0.02 mas at the peak, which is a very significant value. In Fig. 2 shows smoothed dependences for different stellar magnitudes, where dependence on intensity is clearly visible. For stars with $15^{\mathrm{m}}(\mathrm{O}-\mathrm{C})$ values oscillate around zero, for $11^{\mathrm{m}}$ goes above 0.02 mas.

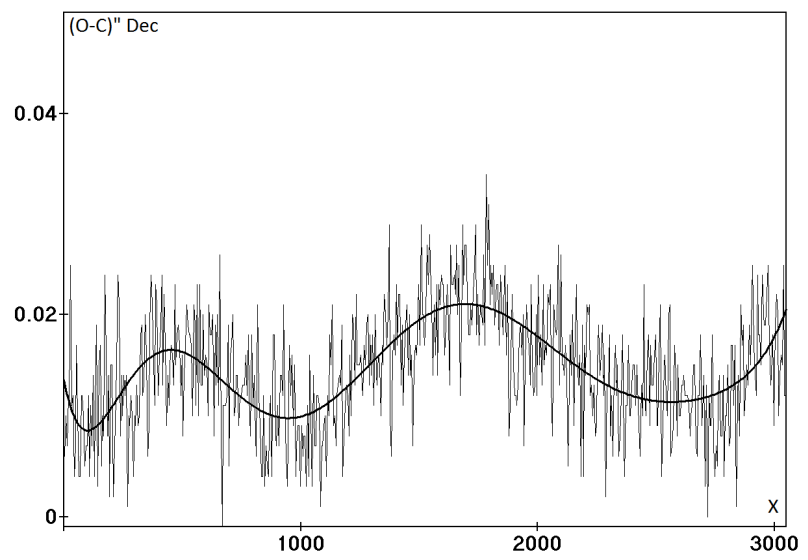

Figure 1: The distribution of $(\mathrm{O}-\mathrm{C})$ of the declination from $\mathrm{X}$ for stars of the 12th magnitude

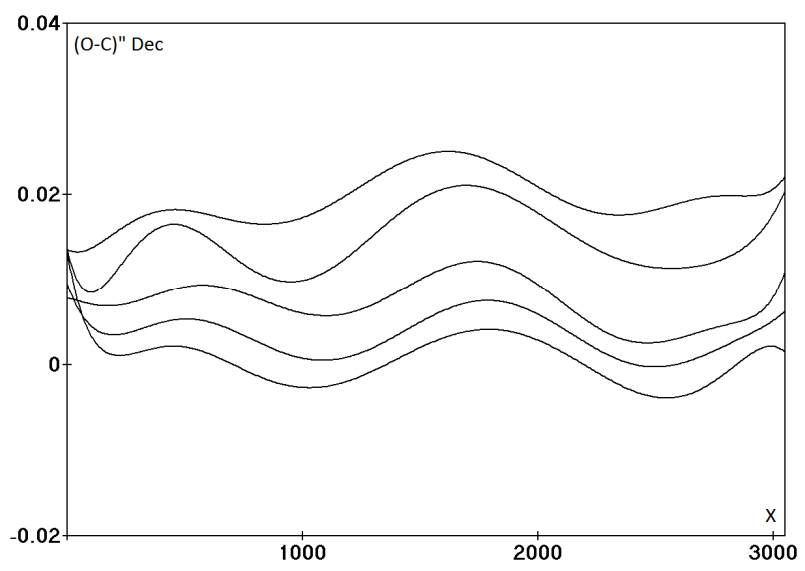

Figure 2: Smoothed distributions of $(\mathrm{O}-\mathrm{C})$ of the declination from $X$, the stars from the 11th to 15 th magnitude (from top to bottom)

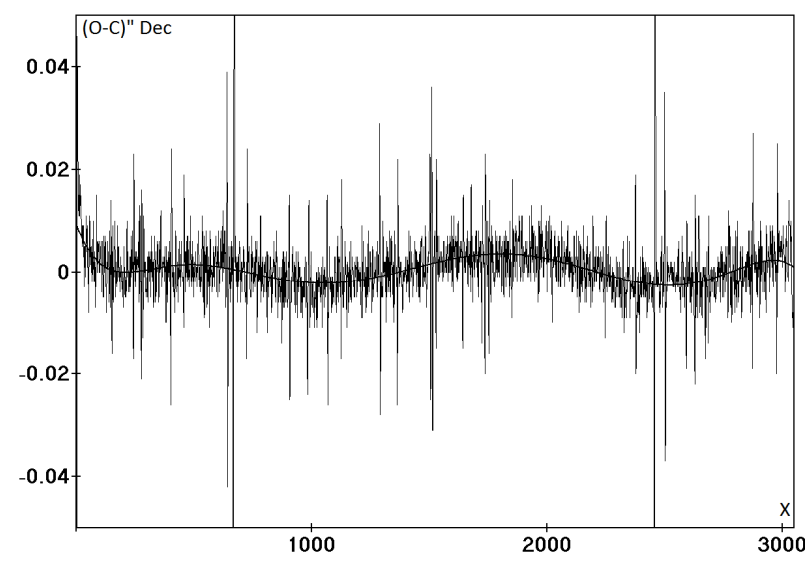

Figure 3: The distribution $(\mathrm{O}-\mathrm{C})$ of the declination from $\mathrm{X}$ for stars of $15^{\mathrm{m}}$ and fainter

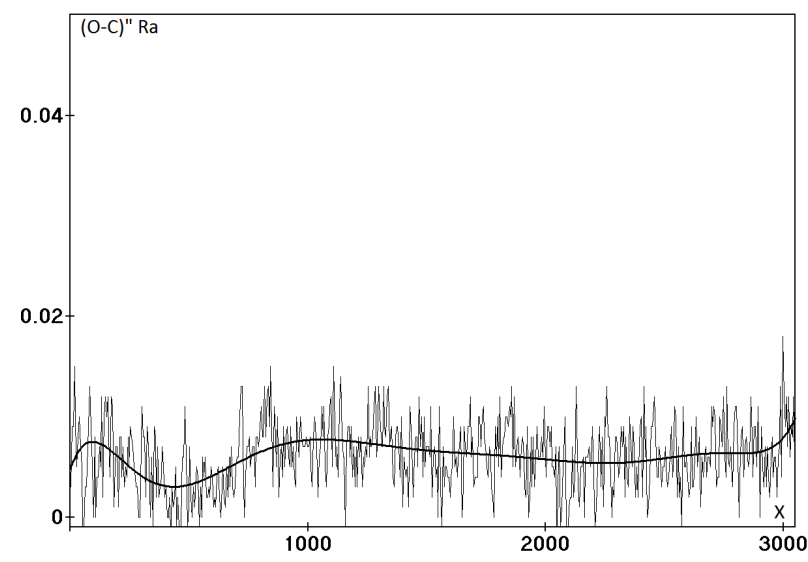

Figure 4: The distribution $(\mathrm{O}-\mathrm{C})$ of the right ascension from $\mathrm{X}$ for stars of $12^{\mathrm{m}}$

An interesting graph of the distribution $(\mathrm{O}-\mathrm{C})$ for low intensities (stars of $15^{\mathrm{m}}$ and fainter) is presented in Fig. 3.

As you can see, the average value $(\mathrm{O}-\mathrm{C})$ is small, but on the graph, there is a certain amount of emissions reaching 0.05 mas and more. Such anomalous behaviour $(\mathrm{O}-\mathrm{C})$ is explained by the presence of CCD matrix defects, the most significant of them are visible on the images in the form of light or dark columns. Others are not visible with the eye, but if the image of the star gets on them in the process of observations, it adduce to a significant increase of coordinate errors.

Similar data were obtained for $(\mathrm{O}-\mathrm{C})$ of right ascension and presented in Fig. 4 and 5.

As can be seen from the graphs, the nature of the error behaviour is different than for the declination axis. This is explained by the mode of operation of the CCD camera, namely, the synchronous charge transfer which adduces to averaging errors across the field exactly on the axis of right ascension. Also, there are practically no abnormal jumps in the values of $(\mathrm{O}-\mathrm{C})$ on $\mathrm{CCD}$ defects; this is also the effect of synchronous charge transfer. 


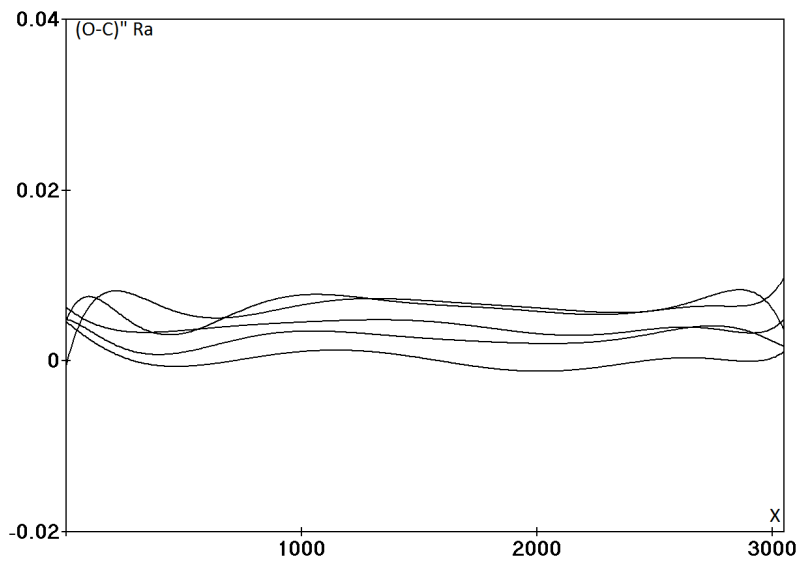

Figure 5: Smoothed distributions of $(\mathrm{O}-\mathrm{C})$ of the RA from $\mathrm{X}$, the stars from the $11^{\mathrm{m}}$ to $15^{\mathrm{m}}$ (from top to bottom)

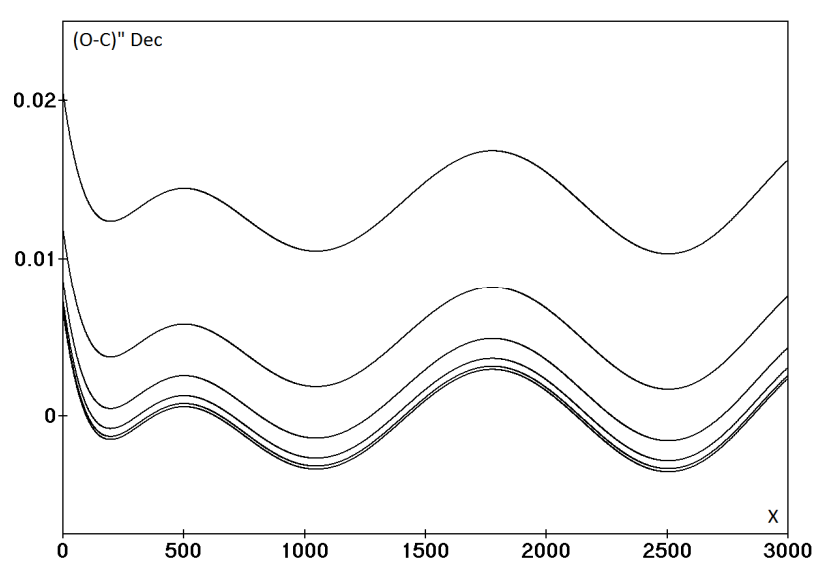

Figure 6: Analytical dependence of distributions of $(\mathrm{O}-\mathrm{C})$ of the declination from $\mathrm{X}$, the stars from the 11 th to 15 th magnitude (from top to bottom)

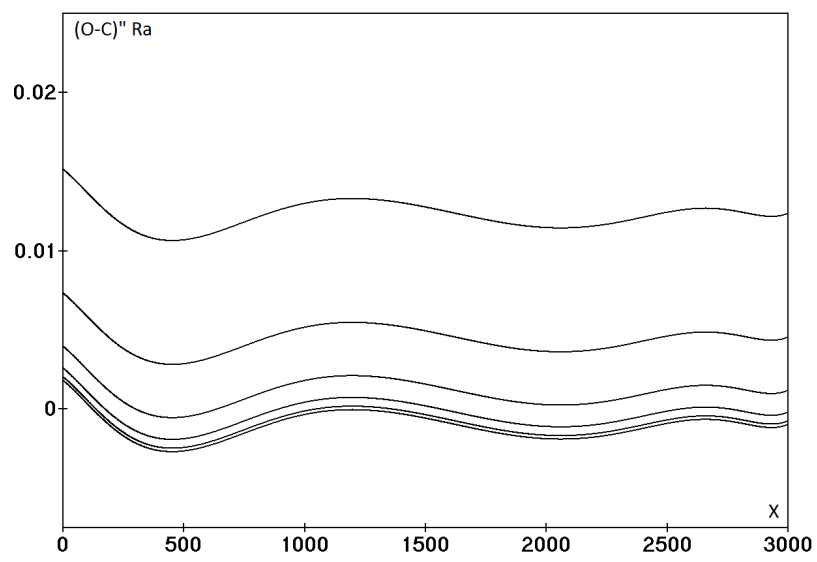

Figure 7: Analytical dependence of distributions of $(\mathrm{O}-\mathrm{C})$ of the right ascension from $\mathrm{X}$, the stars from the 11th to 15 th magnitude (from top to bottom)
To construct an analytical dependence, we used the method of least squares, which is based on the 10th degree polynomial from the $\mathrm{X}$, and the 3 rd degree from the integral intensity. The coefficients of polynomial were calculated in three iterations and we discarding the samples with too large values $(\mathrm{O}-\mathrm{C})$ by the criterion of $3 \sigma$. The result is in the form of graphs below.

\section{Conclusion}

As can be seen from the graphs obtained, the system of (O-C) has a significant value for objects with high intensity, namely for stars brighter than the 13th magnitude. Also, an abrupt increase of $(\mathrm{O}-\mathrm{C})$ values are observed for images gets on the CCD columns containing defects.

Similar studies have also been carried out for a lot of CCD frames obtained from astronomical databases for other instruments (Protsyuk et al., 2015). They showed similar results for some telescopes.

The results of the investigation will be used to improve the accuracy of astrometric catalogues obtained with the KT50 telescope and to improve the accuracy of the proper motions of stars in the vicinity of open clusters.

\section{References}

Apogee Alta CCD Camera, [online] Available at:(https://optcorp.com/products/apogee-alta-f9000d07-monochrome-ccd-camera)

[Accessed 19 September 2018].

Protsyuk Yu.I., Martynov M.V., Mazhaev A.E.: 2014, Kinem. Phys. Cel. Bodies., 30, N6, 296.

Protsyuk Yu.I., Kovalchuk O.M.: 2015, Odessa Astron. Publ., 28, 207.

Protsyuk Yu.I., Kovalchuk O.M., Mazhaev O.E.: 2017, Sci.Innov., 13, N1, 54.

Raab H., Astrometrica, [online] Available at: (http://www.astrometrica.at/) [Accessed 19 September 2018].

Shulga O.V., Kozyryev Y.S., SybiryakovaY.S. et al.: 2012, KosNT., 18, N4, 52.

Zacharias N., Finch C.T., Girard T.M. et al.: 2013, Astron. J. 145, 44. 